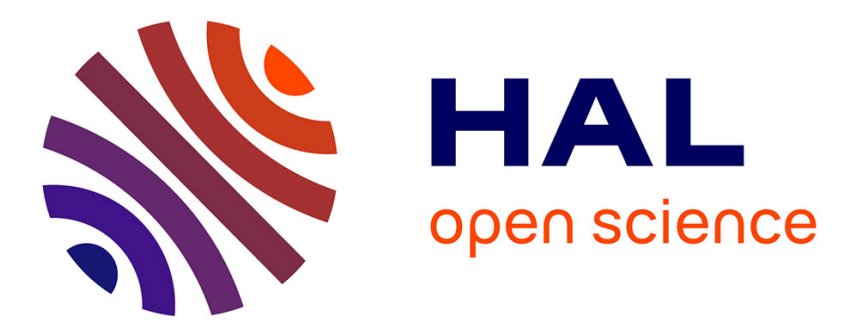

\title{
Biodiversity assessment following a naturality gradient of riverbank protection structures in French prealps rivers
}

Paul Cavaillé, Fanny Dommanget, Nathan Daumergue, Gregory Loucougaray, Thomas Spiegelberger, Eric Tabacchi, André Evette

\section{To cite this version:}

Paul Cavaillé, Fanny Dommanget, Nathan Daumergue, Gregory Loucougaray, Thomas Spiegelberger, et al.. Biodiversity assessment following a naturality gradient of riverbank protection structures in French prealps rivers. Ecological Engineering, 2013, vol. 53, pp. 23-30. 10.1016/j.ecoleng.2012.12.105 . hal-00959127

\section{HAL Id: hal-00959127 \\ https://hal.science/hal-00959127}

Submitted on 14 Mar 2014

HAL is a multi-disciplinary open access archive for the deposit and dissemination of scientific research documents, whether they are published or not. The documents may come from teaching and research institutions in France or abroad, or from public or private research centers.
L'archive ouverte pluridisciplinaire HAL, est destinée au dépôt et à la diffusion de documents scientifiques de niveau recherche, publiés ou non, émanant des établissements d'enseignement et de recherche français ou étrangers, des laboratoires publics ou privés. 


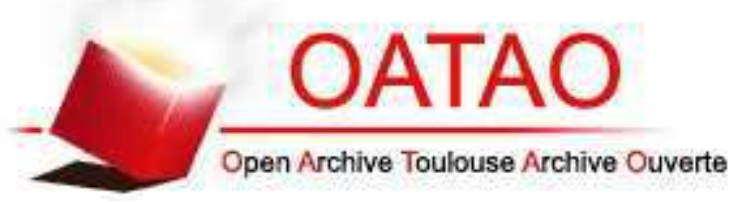

\section{Open Archive TOULOUSE Archive Ouverte (OATAO)}

OATAO is an open access repository that collects the work of Toulouse researchers and makes it freely available over the web where possible.

This is an author-deposited version published in : http://oatao.univ-toulouse.fr/ Eprints ID : 11172

To link to this article : doi:10.1016/j.ecoleng.2012.12.105

URL : http://dx.doi.org/10.1016/j.ecoleng.2012.12.105

To cite this version : Cavaillé, Paul and Dommanget, Fanny and Daumergue, Nathan and Loucougaray, Gregory and Spiegelberger, Thomas and Tabacchi, Eric and Evette, André Biodiversity assessment following a naturality gradient of riverbank protection structures in French prealps rivers. (2013) Ecological Engineering, vol. 53 . pp. 2330. ISSN 0925-8574

Any correspondance concerning this service should be sent to the repository administrator: staff-oatao@ listes-diff.inp-toulouse.fr 


\title{
Biodiversity assessment following a naturality gradient of riverbank protection structures in French prealps rivers
}

\author{
Paul Cavailléa,*, Fanny Dommanget ${ }^{\mathrm{a}}$, Nathan Daumergue ${ }^{\mathrm{a}}$, Gregory Loucougaray ${ }^{\mathrm{a}}$, \\ Thomas Spiegelberger ${ }^{\mathrm{a}}$, Eric Tabacchi ${ }^{\mathrm{b}}$, André Evette $^{\mathrm{a}}$ \\ a Irstea, UR EMGR, 2 rue de la papeterie BP 76, 38402 Saint-Martin-d'Hères, France \\ ${ }^{\mathrm{b}}$ CNRS, University of Toulouse, Institut National Polytechnique, EcoLab, Bât. 4R1, 118 route de Narbonne, 31062 Toulouse cedex 9, France
}

Keywords:

Beetle diversity

Bioengineering

Plant diversity

Riverbank

Riparian corridors

\begin{abstract}
A B S T R A C T
Erosion control of riverbank is frequently necessary to protect human investments situated along rivers. The technique chosen for such erosion control construction may have major impacts on biodiversity and on the functioning of river corridors. Even if there is agreement, that biodiversity should be one criterion for choosing embankments techniques little is known about whether such techniques can accommodate biodiversity.

We aimed to determine coleopteran and plant taxonomic diversities along a naturality gradient of riverbank protection systems, ranking from entirely civil engineering structures, through combined constructions (mixing civil engineering and bioengineering), to purely bioengineering structures.

Fifteen sites (five sites of each technique) were sampled in the Rhône-Alpes region (S.E. France). On each site, vegetation was sampled along three transects from the bottom to the top of the riverbank and flying beetles by trapping.

In total, we recorded 148 plant species and 78 beetle genera. We found significantly lower animal and plant diversities within civil engineering constructions than in the other two techniques. Diversities of both techniques tended to be higher, although not significantly, in combined techniques than in purely bioengineering ones. Furthermore, civil engineering structures were more subject to invasion by exotic plant species than the two other techniques. These results quantify and highlight the interest of bioengineering techniques compared to civil engineering in enhancing biodiversity and limiting invasive species techniques.
\end{abstract}

\section{Introduction}

In addition to its high level of biodiversity, riparian corridors supply multiple ecosystem services such as nutrient control, flood control, shading effect and social aspects. Riparian corridors have therefore been widely recognized as key component in landscapes (Décamps, 2011). There is a strong causal linkage between biodiversity and ecosystem functioning (Maestre et al., 2012). Biodiversity loss may induce a modification of natural ecosystem functioning and ecosystem services (McNeely, 2010).

However, Western European riparian corridors and their vegetation have been widely affected by centuries of human use. River corrections and associated flood control have been primarily perceived has a great human achievement in environmental

\footnotetext{
* Corresponding author.

E-mail address: paul.cavaille@irstea.fr (P. Cavaillé).
}

control. However, shortly after initial success such artificial landscapes spotlight a major conflict between riparian ecosystem conservation and human patrimony protection (Pahl-Wostl, 2006), as such river straightening has lead to a drastic loss of biodiversity in riparian systems. In urbanized areas as well as in agricultural landscapes, space available for riparian vegetation is often reduced to the riverbank only. Thus, organisms can hardly circulate along there remnants of the past riparian corridors especially when civil engineering erosion control structures are used (Nilsson et al., 2005). Such interruptions in the corridor mosaic may lower biological continuity by reducing circulation, refuge and feeding opportunities, and by increasing thermal contrasts during summer. Altered landscapes and disrupted corridor result in a global riparian ecosystem loss (Poff et al., 1997; Tockner and Stanford, 2002). Consequently, biodiversity conservation should be a strategy for practitioners to enhance ecosystem functioning (Isbell et al., 2011).

In addition, direct exposure to flood and high flood frequency lead to high propagule fluxes on bare soils and promote 
colonization by exotic species and subsequently invasion (Décamps et al., 1995). Therefore, exotic species richness is significantly greater in riparian zones compared to upland sites (Stohlgren et al., 1998).

Habitat restoration has been clearly identified as a key element to reverse negative anthropic impacts on biodiversity and ecosystems functioning (Helfield et al., 2012). Public policy such as the European Water Framework Directive (WFD; 2000/60/EC) encourages a global "good ecological status" of aquatic environment including morphological conditions such as structure of the riparian zone. A study ordered in 2005 by the French Ministry of Ecology and Sustainable Development highlights that 51\% of the surface water mass would not reach the objective of "good ecological status" by 2015 (IFEN, 2006). Improving biodiversity on artificial riverbanks may act in favour of this objective and in particular if alternatives to civil engineering are used such as bioengineering techniques (Li and Eddleman, 2002).

Bioengineering techniques for erosion control consists in the uses of living plants in order to mimic natural vegetation able to resist intense scouring (Gray and Sotir, 1996; Norris et al., 2008; Evette and Frossard, 2009). Bioengineering applied to riverbanks aims at combining both artificial and natural components to provide protection at the entire bank level (Evette et al., 2012). In addition to their erosion control capacity, bioengineering structures are supposed promoting the recovery of indigenous species and to ensure better plant coverage than artificially reconstructed embankments using civil engineering techniques (Pezeshki et al., 2007). One of the arguments given for choosing bioengineering structures instead of civil engineering ones is that the first promote the re-establishment of a functional and self-sustainable ecosystem; however, to our knowledge, no quantitative scientific evidences have been produced to support this idea. Until now socio-economical issues are the main reasons to whether protect or not. River and land managers' final decision on which riverbank protection technique will be used is mainly based on several crucial points such as hydro-engineering aspects, bed material and watercourse bank stability (Schiechtl and Stem, 1996). However, no quantitative ecological aspect is for the moment taken into account in the decision line.

To date, many scientific studies on bioengineering structures along rivers focus on methodological aspects such as structures, construction methods, mechanical resistance and the choice of species (Breton et al., under review), compared to the few works which are dedicated to biodiversity subsequently related to erosion control structures on watercourse banks. Since 2002 and the early work on the environmental and ecological advantages of bioengineering structures (Li and Eddleman, 2002), few studies have used quantitative methods to investigate relation between biodiversity and erosion control structures. Some works are dealing with plant species and habitat diversity assessment but remain study cases on very few sites (Li et al., 2006; Sudduth and Meyer, 2006). On the other hand, studies have been done on riverbank restoration by removing bank fixation or protection and comparative biological survey on restored and non-restored sites were made (Helfield et al., 2007; Januschke et al., 2011). Though there is a big knowledge gap concerning quantitative biological comparison of riverbank techniques for erosion control and their impact on ecosystem properties (Pahl-Wostl, 2006). To our knowledge, no study has yet demonstrated the relationship between materials and techniques used for erosion control and associated changes in biodiversity on the constructions.

The aims of this study were (i) to evaluate and compare animal and vegetal biodiversity on three riverbank techniques for erosion control and (ii) to assess the capacity of different riverbank protection techniques to limit invasion of exotic species. The applied aim of this study was to integrate ecological aspects into the decision line by providing ecological data. We provide guidelines to practitioners on what ecological conditions they can expect on the riverbank technique chosen in order to develop strategies linked to riverbank management and allow restoration of ecosystem goods and services. We hypothesize that civil engineering techniques do not promote biodiversity as good as bioengineering techniques.

\section{Materials and methods}

\subsection{Sites}

We assessed biological diversity on five replicates of three riverbank techniques (Fig. 1):

- Civil engineering embankments: riprap protection (rocks used to stabilize shorelines, against scour and erosion) noted as "Mineral".

- Mixed embankments combining civil engineering techniques (riprap at the lower part of the bank) and bioengineering techniques (cuttings and woody plantation at the upper part) noted as "Mixed".

- Completely bioengineering embankments: (willow fascines at the lower part of the bank with cuttings and woody plantation at the upper part) noted as "Vegetal".

These three techniques were considered as three level of a naturality gradient. Naturality can be defined by the amount of living vegetation used in the construction as classification key criterion (Brunel, 2009; Werdin-Pfisterer et al., 2009). Mineral structures were considered as man-made environments with little plant coverage, different from the environment found on natural mountain riverbank. Mixed methods show intermediate plant cover with revegetation on half of the bank. Bioengineering structures are completely vegetal and therefore are expected to show the highest vegetation cover and thus the highest level of naturality. These three engineering techniques therefore constitute three distinct levels on a naturality gradient.

We selected fifteen riverbanks along six distinct French prealps rivers belonging to the Rhone catchment area. A large and intense prospection at territorial units for river management organizations was performed to list enough comparable banks. Table 1 lists sites characteristics. As altitude profoundly affects ecological community composition, study sites were selected at a narrow range of $270 \mathrm{~m}$ (between 200 and $470 \mathrm{~m}$ asl). Only sites between 20 and $30 \mathrm{~m}$ long and with an established vegetation were chosen for analysis. All the study sites were located in the foothills of the French Alps characterized by highly fragmented habitats.

\subsection{Vegetation}

Vegetation was assessed using the contact point method in June and July 2009. This method encompasses the vertical organization of the vegetation (tree, shrub and herbaceous layers). Plant species diversity and frequencies were estimated using a 2-m-long stick with a diameter of $1 \mathrm{~cm}$. Measurements were taken every metre along three $20 \mathrm{~m}$ transects placed parallel to the shore one located at the water line (Transect 1), one in the middle (Transect 2 ) and one at the top (Transect 3) of the riverbank embankment (sixty measurements per site). Vegetation was identified to the species level using various identification keys and flora (Rameau, 1994; Lauber and Wagner, 1998; Aeschimann et al., 2004). Exotic species were defined on the basis of established lists relevant to the area (Muller et al., 2006), a list of exotic invaders in Switzerland 




Fig. 1. Schematic representation of riverbank techniques studied. (a) Civil engineering embankments: riprap protection, noted as "Mineral". (b) Mixed embankments combining civil engineering (riprap at the lower part of the bank) and bioengineering techniques, noted as "Mixed". (c) Completely bioengineering embankments: willow fascines at the lower part of the bank with cuttings, noted as "Vegetal".

(Landolt and Bäumler, 2010) and a list established for the administrative district of Isère (Gentiana, 2006).

\subsection{Fauna}

Coleopterans were identified to genus (Insecta, Coleoptera). This order, and more specifically the Carabids, is used as proxy for habitat diversity, hydromorphological processes and habitat health status (Boscaini et al., 2000; Kleinwaïchter et al., 2003). Moreover, morphological attributes of Coleopterans can provide information on their functional and trophic status (Van Looy et al., 2005). Flying coleopterans were trapped using two Flora ${ }^{\circledR}$ "Yellow Well" traps, located at the two extremities in the middle of the bank (transect 2) and placed at the canopy level. Traps were set in June and
July 2009 and remained in the field for seven days. Insects were identified using a binocular microscope and appropriate reference works (Picard, 1929; Paulian, 1941; Hoffmann, 1945; Guignot, 1947; Balachowsky, 1949).

\subsection{Statistical analysis}

Differences in plant species and coleopteran genera richness, and in frequency and number of exotic species among the three types of development was assessed using Kruskal-Wallis tests. In case of a significant main effect, paired Mann-Whitney tests were carried out to detect differences between each technique. Overall statistical risk was assessed using the Holm's correction (Holm, 1979). An inter-class principal component analysis (PCA) (Doledec

Table 1

Characteristics and localizations of embankments.

\begin{tabular}{|c|c|c|c|c|c|c|c|}
\hline Site code & Construction type & Locality & River & Latitude & Longitude & Construction work year & Altitude ( $\mathrm{m}$ asl) \\
\hline $6 \mathrm{~V}$ & Vegetal & Les Echelles & Guiers vif & $45^{\circ} 26^{\prime} 19.15^{\prime \prime} \mathrm{N}$ & $5^{\circ} 45^{\prime} 36.75^{\prime \prime} \mathrm{E}$ & 2005 & 393 \\
\hline $35 \mathrm{~V}$ & Vegetal & Villard Bonnot & Vorz & $45^{\circ} 15^{\prime} 01.29^{\prime \prime} \mathrm{N}$ & 5॰54’01.62"E & 2006 & 242 \\
\hline $7 \mathrm{~V}$ & Vegetal & St Geoire en Valdaine & Ainan & $45^{\circ} 28^{\prime} 02.24^{\prime \prime} \mathrm{N}$ & $5^{\circ} 39^{\prime} 40.90 \prime \mathrm{E}$ & 2004 & 381 \\
\hline $38 \mathrm{~V}$ & Vegetal & Le Grand Serre & Galaure & $45^{\circ} 15^{\prime} 45.62^{\prime \prime} \mathrm{N}$ & 5॰06'29.65"E & 2007 & 370 \\
\hline $39 \mathrm{~V}$ & Vegetal & Cluse & Arve & $46^{\circ} 04^{\prime} 13.98^{\prime \prime} \mathrm{N}$ & 6 33'18.72"E & 2005 & 470 \\
\hline $6 \mathrm{Mix}$ & Mixed & Les Echelles & Guiers vif & $45^{\circ} 26^{\prime} 19.15^{\prime \prime} \mathrm{N}$ & $5 \circ 45^{\prime} 36.75$ "E & 2005 & 393 \\
\hline 30Mix & Mixed & Grenoble & Isère & $45^{\circ} 11^{\prime} 55.65^{\prime \prime} \mathrm{N}$ & $5^{\circ} 44^{\prime} 02.36^{\prime \prime} \mathrm{E}$ & 2002 & 210 \\
\hline 32Mix & Mixed & Gière & Isère & $45^{\circ} 11^{\prime} 20.94^{\prime \prime} \mathrm{N}$ & 5'47'20.62"E & 2005 & 210 \\
\hline 39Mix & Mixed & Cluse & Arve & $46^{\circ} 04^{\prime} 13.98^{\prime \prime} \mathrm{N}$ & 6 33'18.72"E & 2005 & 470 \\
\hline 40Mix & Mixed & Bonneville & Arve & $46^{\circ} 04^{\prime} 33.18^{\prime \prime} \mathrm{N}$ & $6^{\circ} 24^{\prime} 26.63$ "E & 2004 & 444 \\
\hline 7Min & Mineral & St Geoire en Valdaine & Ainan & $45^{\circ} 28^{\prime} 02.24^{\prime \prime} \mathrm{N}$ & $5{ }^{\circ} 39^{\prime} 40.90 " \mathrm{E}$ & 2004 & 381 \\
\hline 35Min & Mineral & Villard Bonnot & Vorz & $45^{\circ} 15^{\prime} 01.29^{\prime \prime} \mathrm{N}$ & 5॰54’01.62"E & 2006 & 242 \\
\hline 37Min & Mineral & Chateauneuf de Galaure & Galaure & $45^{\circ} 14^{\prime} 09.59 " \mathrm{~N}$ & $48^{\prime} 30.83^{\prime \prime E}$ & 2004 & 257 \\
\hline 38Min & Mineral & Le Grand Serre & Galaure & $45^{\circ} 15^{\prime} 45.62^{\prime \prime} \mathrm{N}$ & 5 06'29.65"E & 2007 & 370 \\
\hline 39Min & Mineral & Cluse & Arve & $46^{\circ} 04^{\prime} 13.98^{\prime \prime} \mathrm{N}$ & 6॰33'18.72"E & 2004 & 470 \\
\hline
\end{tabular}




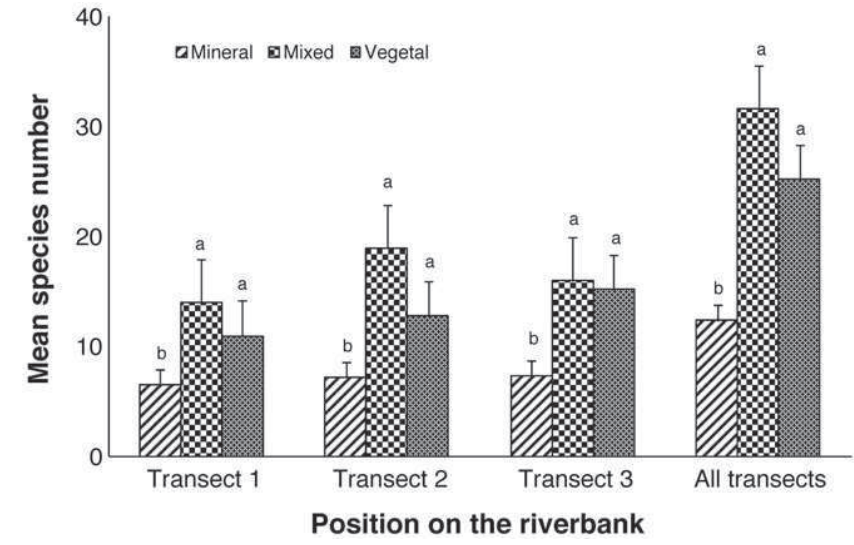

Fig. 2. Mean plant species numbers for each riverbank protection technique according to their positions on the bank. Different letters indicate a statistical difference between samples. Error bars indicate standard errors. The "All transect" bar represent the mean of the total number of plant species found for each technique.

and Chessel, 1987) was carried out to analyze the overall plant pattern. A Monte-Carlo test was processed to detect significant differences in floristic composition on structures using different engineering techniques (Metropolis and Ulam, 1949). All tests were performed using $R$ statistical language $(R, 2005)$ with ade4 package (Thioulouse et al., 1997) for multivariate analysis.

\section{Results}

\subsection{Vegetation}

We identified 126 plant species from the 15 sampled sites.

Plant species richness differed along the naturality gradient (Kruskal-Wallis test: $p$-value $=0.006$, Table 2 ). "Vegetal" or "Mixed" techniques having higher species plant diversity compared to "Mineral" technique (Mann-Whitney $U$ test with Holm correction: $p$-value $=0.024$ and 0.036 , Table 2 ). There was no significant difference between mean species richness on "Vegetal" and "Mixed" techniques although diversity tended to be higher on the latter, especially in the middle and at the bottom of the bank (Fig. 2).

Floristic composition differed significantly along the naturality gradient (Monte-Carlo test: $p$-value $=0.003$ ). The distribution and spacing of the three spherical clusters (mn: Mineral; mx: Mixed; v: Vegetal) on the PCA factorial map provides information on the variability of floristic compositions (Fig. 3). However, some species contribute more than others to the segregation of the three sets, e.g. multiple Salicaceae species (Salix viminalis L., Salix purpurea L., Salix triandra L., Salix fragilis L., Salix myrsinifolia Salisb. and Salix pentandra L.) characterized "Vegetal" technique. "Mineral" technique was characterized by species like Buddleja davidii Franch., Humulus lupulus L., Robinia pseudoacacia L., Urtica dioica L. and Parthenocissus quinquefolia L. "Mixed" technique was mainly characterized by the presence of Cornus sanguinea L., Calamagrostis epigeios L., Salix incana L., Viburnum opulus L. and Lonicera xylosteum L. (Fig. 4). The inertia of the inter-class analysis represents $18.19 \%$ of the total variance among the sites. In addition, $66.16 \%$ of the information explained by this inter-class PCA was explained by axis 1 . Salicaceae species as well as shrubs like $C$. sanguinea and $V$. opulus mainly explained axis 1 component on the positive side of the axis, and to a lesser extent by species like B. davidii and $R$. pseudoacacia on the negative side. Axis 2 expressed $33.84 \%$ of the information. In the upper part of this axis, the discriminatory species were mainly: $S$. viminalis, S. purpurea and S. triandra. In the lower part, C. sanguinea,

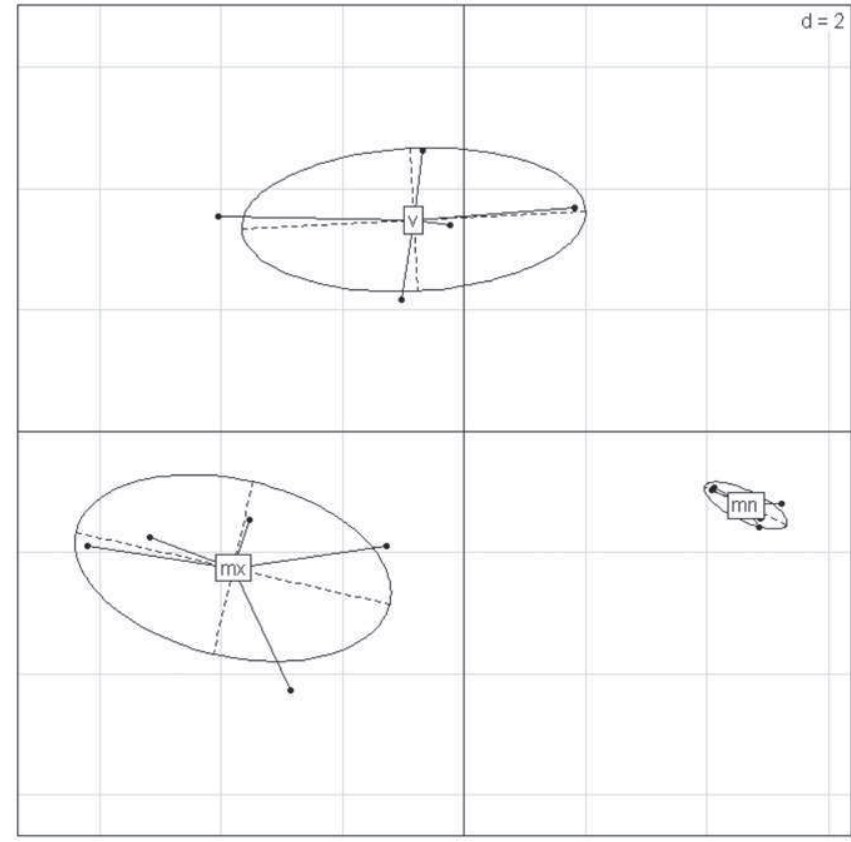

Fig. 3. Inter-class analysis of vegetation on three riverbanks protection technique $\mathrm{mn}$ : Mineral; mx: Mixed; v: Vegetal. The distribution and spacing between the three spherical clusters provides information on the variability of floristic compositions between the different techniques. The size of the ellipse provides information about intra-technique plant species variability.

C. epigeios, S. incana and V. opulus were the discriminatory species (Fig. 4).

The area of the ellipse provided information about intratechniques plant species variability (Fig. 3). "Mixed" and "Vegetal" techniques show comparable variability of plant species composition, higher than that of "Mineral" technique.

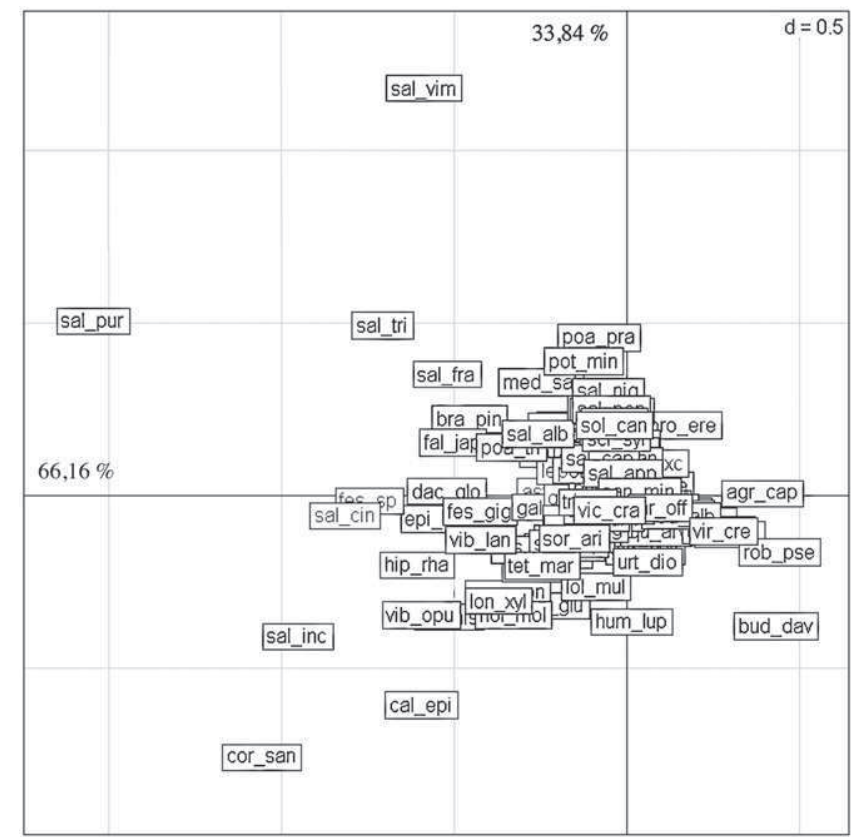

Fig. 4. Spatial distribution of all species encountered on the three riverbanks protection technique. Species codes refer to the first three letters of the genius and the species names. Percentages of variance observed are given on each axis. A correspondence table is given into the supplementary files. 
Table 2

Probability values of the Kruskal-Wallis test and Mann-Whitney test for vegetation survey, flying coleoptera and invasive species.

\begin{tabular}{|c|c|c|c|c|c|}
\hline \multirow[t]{2}{*}{ Statistical tests } & \multirow[t]{2}{*}{ Pair wise comparison } & \multirow{2}{*}{$\begin{array}{l}\text { Vegetation survey } \\
\text { Probability values }\end{array}$} & \multirow{2}{*}{$\begin{array}{l}\text { Aerian coleoptera } \\
\text { Probability values }\end{array}$} & \multicolumn{2}{|c|}{ Invasive species } \\
\hline & & & & Number & Frequency \\
\hline \multirow[t]{2}{*}{ Kruskal-Wallis } & & $0.006^{* *}$ & $0.006^{* *}$ & 0.308 & $0.027^{*}$ \\
\hline & Vegetal/Mixed & 0.247 & 0.083 & 0.817 & 1 \\
\hline \multirow[t]{2}{*}{ Mann-Whitney } & Mixed/Mineral & $0.024^{*}$ & $0.03^{*}$ & 0.363 & 0.063 \\
\hline & Vegetal/Mineral & $0.036^{*}$ & $0.038^{*}$ & 0.812 & $0.045^{*}$ \\
\hline
\end{tabular}

${ }^{*}$ Indicate statistical significant differences $(p$-value $<0.05)$.

** Indicate highly significant differences $(p$-value $<0.01)$

\subsection{Fauna}

We identified 42 distinct genera of flying Coleoptera from the 14 sampled sites (every traps have been lost for one site from the "Vegetal" technique). Fig. 5 indicates the mean numbers of flying Coleoptera genera collected in Flora ${ }^{\circledR}$ yellow traps for each three techniques. "Vegetal" supported a mean of 12.2 different genera of coleopterans, "Mixed" ones supported 7.2 and "Mineral" techniques supported 3.0 genera. A genius names list was included in supplementary files.

Riverbank techniques significantly influenced the number of coleopteran genera (Kruskal-Wallis $p$-value $=0.006$, Table 2) "Mixed" and "Vegetal" techniques were significantly richer than "Mineral" technique (Mann-Whitney $U$ test with Holm correction: $p$-value $=0.03$ and 0.038 ; Table 2 ).

We observed many genera associated with Salicaceae including various saproxylic Cetonia species with larvae growing in decomposing wood (Cetonia aurata, Potosia cuprea bourginii). There were also Cerambycidae species like Lamia textor, of which the larvae develop in willow stumps and roots, Necydalis major in the high cavities of trees, and Aromia moschata, of which the larvae develop in rotting stumps and branches. Many herbivorous coleopteran species were identified, especially Variimorda ssp. (often seen on Apiaceae), Hoplia farinosa (which feeds on pollen), Oedemera ssp. (the adult of which is herbivorous and the larva xylophagous). Some were associated with Salicaceae like C. aurata, Chaetocnema aridula and Altica aenescens. Predatory species were also identified, including the carnivorous Adrastus limbatus and Orchesia micans.

\subsection{Exotic plant species}

Although exotic plant species were sometimes found on sites that have been constructed using bioengineering, they were not among the ten dominant species observed in the study. In contrast, two exotic species, B. davidii and $R$. pseudoacacia, belong



Fig. 5. Coleoptera mean genus numbers in yellow traps on the three riverbanks protection technique. Different letters indicate a statistical difference between samples. Error bars indicate standard errors.



Fig. 6. Exotic mean species numbers on the three riverbanks protection technique. Different letters indicate a statistical difference between samples. Error bars indicate standard errors.

to the ten most abundant species on "Mineral" structure $(100 \%$ of observed exotic species). Fallopia sp. was the main genius represented on "Mixed" structure (83\% of observed exotic species) and on "Vegetal" structure ( $100 \%$ of observed exotic species). Overall exotic species richness varied from 1.75 to 2.2 between the techniques (Fig. 6) and did not differ significantly between the three techniques (Kruskal-Wallis test $p$-value $=0.308$; Table 2). Invasive species frequency was significantly different according to the technique (Kruskal-Wallis test $p$-value $=0.027$; Fig. 7 ), reaching a maximum on mineral developments (42.5) compared to vegetal (10) and mixed (13). Frequency of invasive species was significantly different between "Mixed" and "Mineral" techniques but not between "Vegetal" and "Mixed" techniques because of high variability on "Vegetal" developments (from $f=0.34$ to $f=22.71$; Mann-Whitney $U$ test with Holm correction: $p$-value $=0.063$ and 0.045; Table 2). Exotic invasive species were different according to the technique.

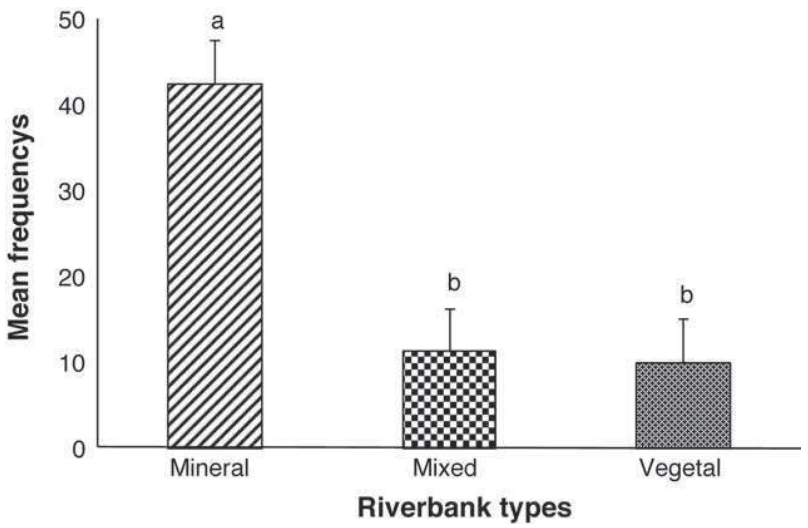

Fig. 7. Exotic mean species frequencies on the three riverbanks protection technique. Different letters indicate a statistical difference between samples. Error bars indicate standard errors. 


\section{Discussion}

\subsection{Vegetation diversity}

This survey provides a first assessment of plant species and Coleoptera genera richness associated with three categories of riverbank protection techniques. Based on field observations, we highlight significant differences in plant diversity between conventional civil engineering and bioengineering. In accordance with our hypothesis, significantly fewer plant species were found construction using on "Mineral" structures than on either of the two others probably due to the substrate in "Mineral" structures that physically limits colonization by plants. In contrast, we observe no significant differences in plant species richness between "Vegetal" and "Mixed" techniques. The higher number of plant species were found on "Mixed" structures compared to "Vegetal" ones may be explained by a large proportion of willows from the fascines installed at the water line which show an important growth rate; willows are part of fast-growing species usually used riverbank bioengineering (Adam et al., 2008). This willow canopy rapidly develops a dense coverage that can partially inhibit colonization of the understory by herbaceous plants. For the "Mixed" technique, the presence of vegetation free riprap at the bottom of the bank restricts colonization and coverage by Salicaceae species to the upper part. Riprap at the interface between the aquatic environment and the first willow cuttings provide open space available for colonization by halophytic species (Chen et al., 2010). This lower part constitutes a different habitat, distinct from that offered by the "Vegetal" technique where woody species, mostly willows, predominate. Species typically found on this "Mixed" structures are (i) typical wetland species like Tetragonolobus maritimus, Juncus acutiflorus, Carex pseudocyperus and Phragmites australis, (ii) meadow species like Holcus mollis, (iii) edge species and species of woodland fringes like Ligustrum vulgare, L. xylosteum and Crataegus monogyna and (iv) trees from alluvial zones like Populus nigra and Populus alba. Most of those species were not found on "vegetal" structures because of the predominance of willows due to a lack of light and space. Finally, periodic sedimentation fills in the gaps between the blocks and creates a loam-rich substrate favourable for colonization by helophytic species. Our results are therefore consistent with other studies where the presence of some litter and loam increases both the density and diversity of pioneer plants (Langlade and Décamps, 1996).

\subsection{Fauna diversity}

Flying Coleoptera were more diverse on "Vegetal" (12.2 genera on average) and "Mixed" (7.2 genera on average) structures which have more complex vegetation and greater floristic diversity than on "Mineral" (3.0 genera on average) structures. Our results are consistent with other studies which show that the abundance of Coleopteran species can be related to the presence of different vegetation strata, from grasses through bushes to trees (Burel, 1989). In general, insect populations--especially Carabidae--depend on vegetation structure and heterogeneous habitats (Verdonschot et al., 2007). Along river corridors, hotspots of biodiversity are principally situated in regions where habitat diversity is high (Tews et al., 2004). Such habitat heterogeneity primarily reflects gradients of disturbance, sediment grain size, moisture and fertility that are tightly linked to river dynamics that recurrently renews the habitat mosaic and drives succession. In particular small and medium floods create more spatial variability and therefore more heterogeneity (Pollock et al., 1998; Helfield et al., 2007).

Although "Mixed" structures harbour greater biodiversity in terms of plant species richness (30 species on average), more genera of flying Coleoptera were found on "Vegetal" structures (12.2 genera on average). This suggests that the plant species identity has a major impact on insect diversity. Salix species probably attracts many nectar-feeding insects by providing an important nectar source available early in the year (in January and February) when other nectar sources are scarce (Newsholme, 1992). The high number of coleoptera associated with Salicaceae found in this study converges with Newsholme's observations. Vegetal cover and biomass were higher on "Vegetal" structures compared to the two others what could explain the higher coleopteran diversity on "Vegetal" structures. Moreover that shore zones contain large number of predators and scavengers including carabid beetles that feed on wrack or carrion that has been deposed on the shore (Kleinwächter et al., 2003). We can assume that "Vegetal" and "Mixed" structures support more vegetation compared to "Mineral" structures and can thus produce more wrack and induce higher animal drowning mortality. In general, shore zones are an important feeding zone for many species including carabid species (Strayer and Findlay, 2010).

\subsection{Invasive species}

This study did not reveal any significant difference in the number of exotic plants between "Mineral", "Mixed" and "Vegetal" techniques (respectively $1.75 ; 2.2$ and 1.8 ). The occurrence of exotic plant species has been often related to the intensity of human activity (Pyšek et al., 2010). All techniques studied involve heavy human intervention like earthmoving or digging activities. It can be assumed that the soils were all subject to an equivalent degree of perturbation and comparable propagule pressure explaining why the different techniques harbour a similar number of exotic plant species. In contrast, this study shows that the frequency of exotic species was higher on "Mineral" structures than on the other techniques. Exotic plants species identified in this study are characterized by high growth rates which gave them a competitive advantage in pioneer habitats (Call and Nilsen, 2003; Tallent-Halsell and Watt, 2009). Moreover the relative abundance of invasive plants could be explained by biotic interactions, notably related to competition (Levine et al., 2004). The presence of competitors on "Mixed" and "Vegetal" structures could restrict the vigour and inhibit the propagation of exotic species what is in particular seen on bioengineering structures; where it is very likely that the high density of willow restricted the performance of exotic species. Interestingly, B. davidii was the only species on "Mineral" technique and Fallopia sp. was the only invasive species on "Vegetal" technique. As mineral structures could experience higher temperatures during sunny weather than vegetalized banks, high temperature on mineral techniques could be here hypothesized as an environmental filter for species sensitive for heat stress. $B$. davidii is a Mediterranean and tropical species, can be supposed to stand high temperatures (Tallent-Halsell and Watt, 2009; Watt et al., 2010). Colonisable substrata available can also be an explanation; Fallopia sp. rhizomes need more space to develop and end up in a viable organism.

\subsection{Perspectives and applications}

The applicative purpose of this study is to provide useful information to decision-makers for planning sustainable management strategies of mountain riverbanks. Along small rivers, riverbank protections should be plant instead of self-recovery of natural vegetation in order to promote a rapid vegetal cover and to limit exotic species invasion. The bioengineering techniques using willows controls erosion, limit colonization by exotic heliophilous species and provides food resources and habitat to entomofauna. 
Salicaceae are particularly adapted to riverbank restoration techniques. The morphological (deep roots, dense coverage), mechanical (flexible wood) and physiological (rapid growth, production of large amounts of nectar and pollen) properties of this genus limit erosion and ensure a good return to naturality (Schiechtl and Stem, 1996; Frossard and Evette, 2009). However, such restoration techniques should always include a large diversity of species and growth forms. Thus, creating different plant strata (grasses, bushes, and trees) ensures habitat diversity. River restoration programme could also aim at increasing habitat diversity. For instance, it is possible to promote the recruitment of helophytic species by creating interface areas between the water and the bank, free of bushes and trees and where sediment can be deposed to facilitate the accumulation of a colonisable substrate. "Mixed" technique with riprap at the base of the bank and bioengineering techniques on the upper part represent a trade-off between vegetal covering and habitat diversity.

Finally yet importantly, bioengineering structures represent a good alternative in the French Environmental Law, as administrative procedures are simpler (Decree n 93-743 of the law 92-3 article 10). For civil-engineering structures, an environmental impact assessment is required what brings the administrative delay to 6-9 months to obtain a construction permit.

\section{Conclusion}

The intensification of human disturbance along mountain river lead to a dramatic decrease in riparian biodiversity. Maintaining biological continuity between small remnant refuge zones is a priority for the conservation of biodiversity threatened species (Miller, 2006). The present study shows the capacities of restoration ecology and, more specifically, bioengineering, to promote the recovery of coleopteran and plants of riparian forests. In addition, "Mixed" and "Vegetal" embankment techniques enhance connectivity between different habitats and thus contribute to the restoration of ecological corridors. Increased connectivity between fragmented landscape patches is likely to increase genetic diversity within modified landscapes (Neaves et al., 2009).

In a further step, this study should be extended to the aquatic compartment. Benthic invertebrates seems to be a good indicator of naturality with their diversity correlated to the amount of organic substrate (wood and roots) on the banks (Sudduth and Meyer, 2006). The questioning could also be raised to a functional analysis of the restored ecosystems (Lavorel and Garnier, 2002; Hooper et al., 2005).

\section{Acknowledgements}

This work would not have been possible without the help of the Eco-Erosion Unit of the Mountain Ecosystem Research Unit of Irstea, Grenoble and the University of Toulouse, CNRS EcoLab, Toulouse. The French-Swiss Interreg IV Project Geni'Alp and the Agence de l'Eau Rhone-Alpes are thanked for providing funding.

\section{Appendix A. Supplementary data}

Supplementary data associated with this article can be found, in the online version, at http://dx.doi.org/10.1016/j.ecoleng. 2012.12.105.

\section{References}

Adam, P., Debiais, N., Gerber, F., Lachat, B., 2008. Le génie végétal, Un manuel technique au service de l'aménagement et de la restauration des milieux aquatiques.
Ministère de l'écologie, du développement et de l'aménagement durables, Paris, 290 pp.

Aeschimann, D., Lauber, K., Moser, D.-M., Theurillat, J.-P., 2004. Flora Alpina. Belin, Bern, 2672 pp.

Balachowsky, A., 1949. Faune de France (tome 50): Coléoptères Scolytides. Lechevalier, Paris, 320 pp.

Boscaini, A., Franceschini, A., Maiolini, B., 2000. River ecotones: carabid beetles as a tool for quality assessment. Hydrobiologia 422, 173-181.

Breton, V., Forestier, O., Guindon, O., Evette, A. Ecological restoration under pressure from invasive animal species: use of Salicaceae cuttings in a river bank. River Research and Applications, under review.

Brunel, J.P., 2009. Sources of water used by natural mesquite vegetation in a semiarid region of northern Mexico. Hydrol. Sci. J. 54 (2), 375-381.

Burel, F., 1989. Landscape structure effects on carabid beetles spatial patterns in western France. Landsc. Ecol. 2 (4), 215-226.

Call, L.J., Nilsen, E.T., 2003. Analysis of spatial patterns and spatial association between the invasive tree-of-heaven (Ailanthus altissima) and the native black locust (Robinia pseudoacacia). Am. Midl. Nat. 150 (1), 1-14.

Chen, S.Y., Zhang, J.L., Jia, P., Xu, J., Wang, G., Xiao, S., 2010. Effects of size variation and spatial structure on plastic response of plant height to light competition. Chin. Sci. Bull. 55 (12), 1135-1141.

Décamps, H., 2011. River networks as biodiversity hotlines. C.R. Biol. 334 (5-6), 420-434.

Décamps, H., Planty-Tabacchi, A.M., Tabacchi, E., 1995. Changes in the hydrological regime and invasions by plant species along riparian systems of the Adour River, France. Regul. Rivers: Res. Manage. 11 (1), 23-33.

Doledec, S., Chessel, D., 1987. Seasonal successions and spatial variables in freshwater environments. I. Description of a complete two-way layout by projection of variables (Rythmes saisonniers et composantes stationnelles en milieu aquatique. I. Description d'un plan d'observation complet par projection de variables). Acta Oecol. 8 (3), 403-426.

Evette, A., Balique, C., Lavaine, C., Rey, F., Prunier, P., 2012. Using ecological and biogeographical features to produce a typology of the plant species used in bioengineering for riverbank protection in europe. River Res. Appl. 28 (10), $1830-1842$.

Evette, A., Frossard, P.A., 2009. Les végétaux ont du génie. Espaces Naturels 26, 35-37.

Frossard, P.A., Evette, A., 2009. Le génie végétal pour la lutte contre l'érosion en rivière: une tradition millénaire en constante évolution. I.E.A.T. 99-109.

Gentiana, 2006. Les espèces envahissantes de l'Isère. Conseil général de l'Isère, Grenoble, $32 \mathrm{pp}$.

Gray, D., Sotir, R., 1996. Biotechnical and Soil Bioengineering Slope Stabilization A Practical Guide for Erosion Control. John Wiley and Sons, Inc., New York, 400 pp.

Guignot, F., 1947. Faune de France (tome 48): Coléoptères Hydrocanthares. Lechevalier, Paris, $294 \mathrm{pp}$

Helfield, J.M., Capon, S.J., Nilsson, C., Jansson, R., Palm, D., 2007. Restoration of rivers used for timber floating: effects on riparian plant diversity. Ecol. Appl. 17 (3), 840-851.

Helfield, J.M., Engström, J., Michel, J.T., Nilsson, C., Jansson, R., 2012. Effects of river restoration on riparian biodiversity in secondary channels of the Pite River, Sweden. Environ. Manage. 49 (1), 130-141.

Hoffmann, A., 1945. Faune de France (tome 44): Coléoptères Bruchides et Anthribides. Lechevalier, Paris, $184 \mathrm{pp}$.

Holm, S., 1979. A simple sequentially rejective multiple test procedure. Scand. J. Stat. $6(2), 65-70$.

Hooper, D.U., Chapin, F.S., Ewel, J.J., Hector, A., Inchausti, P., Lavorel, S., Lawton, J.H., Lodge, D.M., Loreau, M., Naeem, S., Schmid, B., Setala, H., Symstad, A.J., Vandermeer, J., Wardle, D.A., 2005. Effects of biodiversity on ecosystem functioning: a consensus of current knowledge. Ecol. Monogr. 75 (1), 3-35.

IFEN, 2006. L'environnement en France - Edition. IFEN, 500 pp.

Isbell, F., Calcagno, V., Hector, A., Connolly, J., Harpole, W., Reich, P., SchererLorenzen, M., Schmid, B., Tilman, D., van Ruijven, J., Weigelt, A., Wilsey, B., Zavaleta, E., Loreau, M., 2011. High plant diversity is needed to maintain ecosystem services. Nature 477 (7363), 199-202.

Januschke, K., Brunzel, S., Haase, P., Hering, D., 2011. Effects of stream restorations on riparian mesohabitats, vegetation and carabid beetles. Biodivers. Conserv. 20 (13), 3147-3164

Kleinwächter, M., Eggers, T.O., Henning, M., Anlauf, A., Hentschel, B., Larink, O., 2003. Distribution patterns of terrestrial and aquatic invertebrates influenced by different groyne forms along the River Elbe (Germany). Large Rivers 15 (1-4), 319-338.

Kleinwaïchter, M., Larink, O., Eggers, T., Anlauf, A., 2003. Impact of modified groynes on Carabid beetles. In: Proceedings of the "Lowland River Rehabilitation 2003" Conference, Wageningen, The Netherlands.

Landolt, E, Bäumler, B, 2010. Flora indicativa: ökologische Zeigerwerte und biologische Kennzeichen zur Flora der Schweiz und der Alpen=ecological indicator values and biological attributes of the Flora of Switzerland and the Alps. Conservatoire et Jardin botaniques de la ville de Genève, Genève, $376 \mathrm{pp}$.

Langlade, L.-R., Décamps, O., 1996. Effet de l'accumulation de limon sur la colonisation végétale d'un banc de galets en rivière. C.R. Acad. Sci., Paris 318, 1076-1082.

Lauber, K., Wagner, G., 1998. Flora Helvetica, second edition. P. Haupt Editions, Berne/Stuttgart/Vienne, 1614 pp. 
Lavorel, S., Garnier, E., 2002. Predicting changes in community composition and ecosystem functioning from plant traits: revisiting the Holy Grail. Funct. Ecol. $16(5), 545-556$

Levine, J.M., Adler, P.B., Yelenik, S.G., 2004. A meta-analysis of biotic resistance to exotic plant invasions. Ecol. Lett. 7 (10), 975-989.

Li, M.H., Eddleman, K.E., 2002. Biotechnical engineering as an alternative to traditional engineering methods - a biotechnical streambank stabilization design approach. Landsc. Urban Plan. 60 (4), 225-242.

Li, X.P., Zhang, L.Q., Zhang, Z., 2006. Soil bioengineering and the ecological restoration of riverbanks at the Airport Town, Shanghai, China. Ecol. Eng. 26 (3), 304-314.

Maestre, F.T., Quero, J.L., Gotelli, N.J., Escudero, A., Ochoa, V., Delgado-Baquerizo, M., García-Gómez, M., Bowker, M.A., Soliveres, S., Escolar, C., García-Palacios, P., Berdugo, M., Valencia, E., Gozalo, B., Gallardo, A., Aguilera, L., Arredondo, T., Blones, J., Boeken, B., Bran, D., Conceição, A.A., Cabrera, O., Chaieb, M., Derak, M., Eldridge, D.J., Espinosa, C.I., Florentino, A., Gaitán, J., Gatica, M.G., Ghiloufi, W., Gómez-González, S., Gutiérrez, J.R., Hernández, R.M., Huang, X., HuberSannwald, E., Jankju, M., Miriti, M., Monerris, J., Mau, R.L., Morici, E., Naseri, K., Ospina, A., Polo, V., Prina, A., Pucheta, E., Ramírez-Collantes, D.A., Romão, R., Tighe, M., Torres-Díaz, C., Val, J., Veiga, J.P., Wang, D., Zaady, E., 2012. Plant species richness and ecosystem multifunctionality in global drylands. Science 335 (6065), 214-218.

McNeely, J.A., 2010. Biodiversity, Ecosystem Functioning, \& Human Wellbeing: An Ecological and Economic Perspective edited by Shahid Naeem, Daniel E. Bunker, Andy Hector, Michel Loreau and Charles Perrings (2009), xiv +368 pp., Oxford University Press, Oxford, UK. ISBN 9780199547951 (hbk), GBP 75.00; ISBN 9780199547968 (pbk), GBP 37.50. Oryx 44 (03), 461.

Metropolis, N., Ulam, S., 1949. The Monte Carlo method. J. Am. Stat. Assoc. 44 (247), 335-341.

Miller, J.R., 2006. Restoration, reconciliation, and reconnecting with nature nearby. Biol. Conserv. 127 (3), 356-361.

Muller, S., Aboucaya, A., Affre, L., Cassan, S., 2006. Plantes invasives en France, 168 pp.

Neaves, L.E., Zenger, K.R., Prince, R.I.T., Eldridge, M.D.B., Cooper, D.W., 2009. Landscape discontinuities influence gene flow and genetic structure in a large, vagile Australian mammal, Macropus fuliginosus. Mol. Ecol. 18 (16), 3363-3378.

Newsholme, C., 1992. Willows: The Genus Salix. Batsford, London, 226 pp.

Nilsson, C., Reidy, C.A., Dynesius, M., Revenga, C., 2005. Fragmentation and flow regulation of the world's large river systems. Science 308 (5720), 405-408.

Norris, J.E.L., Stokes, A.D., Nicoll, A., Achim, B.C.A., 2008. Species Selection for Soil Reinforcement and Protection. Slope Stability and Erosion Control. Springer. Dordrecht, Ecotechnological Solutions, pp. 167-210.

Pahl-Wostl, C., 2006. The importance of social learning in restoring the multifunctionality of rivers and floodplains. Ecol. Soc. 11 (1), Available online: http://www.ecologyandsociety.org/vol11/iss1/art10/

Paulian, R., 1941. Faune de France (tome 38): Coléoptères Scarabéides. Lechevalier Paris, 240 pp.

Pezeshki, S.R., Li, S., Shields Jr., F.D., Martin, L.T., 2007. Factors governing surviva of black willow (Salix nigra) cuttings in a streambank restoration project. Ecol. Eng. 29 (1), 56-65.
Picard, F., 1929. Faune de France (tome 20): Coléoptères Cerambycîdae. Lechevalier, Paris, $168 \mathrm{pp}$

Poff, N.L., Allan, J.D., Bain, M.B., Karr, J.R., Prestegaard, K.L., Richter, B.D., Sparks, R.E., Stromberg, J.C., 1997. The natural flow regime: a new paradigm for riverine conservation and restoration. Bioscience 47, 769-784.

Pollock, M.M., Naiman, R. J. Hanley, T.A. 1998. Plant species richness in riparian wetlands - a test of biodiversity theory. Ecology 79 (1), 94-105.

Pyšek, P., Jarošík, V., Hulme, P.E., Kühn, I., Wild, J., Arianoutsou, M., Bacher, S. Chiron, F., Didžiulis, V., Essl, F., Genovesi, P., Gherardi, F., Hejda, M., Kark, S., Lambdon, P.W., Desprez-Loustau, M.L., Nentwig, W., Pergl, J., Poboljšaj, K., Rabitsch, W., Roques, A., Roy, D.B., Shirley, S., Solarz, W., Vilà, M., Winter, M., 2010. Disentangling the role of environmental and human pressures on biological invasions across Europe. Proc. Natl. Acad. Sci. U.S.A. 107 (27) 12157-12162.

R, D.C.T., 2005. R: A Language and Environment for Statistical Computing. R Foundation for Statistical Computing, Austria.

Rameau, J.C., 1994. Flore Forestière Française; Tome 1: Plaines Et Collines. Institut Pour Le Développement Forestier. Ministère de l'Agriculture et de la Forêt, Paris $1785 \mathrm{pp}$.

Schiechtl, H.M., Stem, R., 1996. Water Bioengineering Techniques for Watercourse Bank and Shoreline Protection. Blackwell Science, Oxford, UK, 186 pp.

Stohlgren, T., Bull, K., Otsuki, Y., Villa, C., Lee, M., 1998. Riparian zones as havens for exotic plant species in the central grasslands. Plant Ecol. 138 (1), 113-125.

Strayer, D.L., Findlay, S.E.G., 2010. Ecology of freshwater shore zones. Aquat. Sci. 72 (2), 127-163.

Sudduth, E., Meyer, J., 2006. Effects of bioengineered streambank stabilization on bank habitat and macroinvertebrates in urban streams. Environ. Manage. 38 (2), 218-226.

Tallent-Halsell, N.G., Watt, M.S., 2009. The invasive Buddleja davidii (butterfly bush). Bot. Rev. 75 (3), 292-325.

Tews, J., Brose, U., Grimm, V., Tielbörger, K., Wichmann, M.C., Schwager, M., Jeltsch, F., 2004. Animal species diversity driven by habitat heterogeneity/diversity: the importance of keystone structures. J. Biogeogr. 31 (1), 79-92.

Thioulouse, J., Chessel, D., Doledec, S., Olivier, J.M., 1997. ADE-4: a multivariate analysis and graphical display software. Stat. Comput. 7 (1), 75-83.

Tockner, K., Stanford, J.A., 2002. Riverine flood plains: present state and future trends. Environ. Conserv. 29 (3), 308-330.

Van Looy, K., Vanacker, S., Jochems, H., De Blust, G., Dufrene, M., 2005. Ground beetle habitat templets and riverbank integrity. River Res. Appl. 21 (10) 1133-1146.

Verdonschot, R., Noordijk, J., Sykora, K., Schaffers, A., 2007. Ground beetles (Coleoptera: Carabidae) within a vegetation gradient in the Millingerwaard. Entomol. Ber. (Amst.) 67 (3), 82-91.

Watt, M.S., Kriticos, D.J., Potter, K.J.B., Manning, L.K., Tallent-Halsell, N Bourdot, G.W., 2010. Using species niche models to inform strategic management of weeds in a changing climate. Biol. Invasions 12 (11) 3711-3725.

Werdin-Pfisterer, N.R., Kielland, K., Boone, R.D., 2009. Soil amino acid composition across a boreal forest successional sequence. Soil Biol. Biochem. 41 (6) $1210-1220$. 